University of Rhode Island

DigitalCommons@URI

$10-2013$

\title{
A Note on Climate Change Adaptation for Seaports: A Challenge for Global Ports, a Challenge for Global Society
}

\author{
Austin Becker \\ University of Rhode Island, abecker@uri.edu \\ Michele Acciaro \\ Regina Asariotis \\ Edgard Cabrera \\ Laurence Cretegny
}

Follow this and additional works at: https://digitalcommons.uri.edu/maf_facpubs

\section{The University of Rhode Island Faculty have made this article openly available.} Please let us know how Open Access to this research benefits you.

This is a pre-publication author manuscript of the final, published article.

Terms of Use

This article is made available under the terms and conditions applicable towards Open Access Policy Articles, as set forth in our Terms of Use.

\section{Citation/Publisher Attribution}

Becker, A., M. Acciaro, R. Asariotis, E. Carera, L. Cretegny, P. Crist, M. Esteban, A. Mather, S. Messner, S. Naruse, A.K.Y. Ng, S. Rahmstorf, M. Savonis, D. Song, V. Stenek, and A.F. Velegrakis. 2013. "A Note on Climate change adaptation for seaports: A challenge for global ports, a challenge for global society." Climatic Change 120(4): 683-695.

Available at: http://www.dx.doi.org/10.1007/s10584-013-0843-z 


\section{Authors}

Austin Becker, Michele Acciaro, Regina Asariotis, Edgard Cabrera, Laurence Cretegny, Philippe Crist, Miguel Esteban, Andrew Mather, Steve Messner, Susumu Naruse, Adolf K. Y. Ng, Stefan Rahmstorf, Michael Savonis, Dong-Wook Song, Vladimir Stenek, and Adonis F. Velegrakis 


\title{
Title: A note on climate change adaptation for seaports: A challenge for global ports, a challenge for global society
}

\author{
Authors: Austin H. Becker*, Michele Acciaro, Regina Asariotis**, Edgard Cabrera, \\ Laurence Cretegny, Philippe Crist, Miguel Esteban, Andrew Mather, Steve Messner, \\ Susumu Naruse, Adolf K.Y. Ng, Stefan Rahmstorf, Michael Savonis, Dong-Wook Song, \\ Vladimir Stenek, Adonis F. Velegrakis
}

\begin{abstract}
Affiliations: ${ }^{\star}$
*Correspondence to: Austin Becker, Emmett Interdisciplinary Program in Environment and Resources (EIPER), Y2E2 Building -- Suite 226, Stanford University, 473 Via Ortega, Stanford, CA 94305-2210, austinb@stanford.edu.

** The views expressed in this paper represent those of the author and not necessarily those of the UNCTAD secretariat

^See "Table 2 - Table of authors" at end of document
\end{abstract}

\begin{abstract}
With $80 \%$ of world trade carried by sea, seaports provide crucial linkages in global supply-chains and are essential for the ability of all countries to access global markets. Seaports are likely to be affected directly and indirectly by climatic changes, with broader implications for international trade and development. Due to their coastal location, seaports are particularly vulnerable to extreme weather events associated with increasing sea levels and tropical storm activity, as illustrated by hurricane "Sandy". In view of their strategic role as part of the globalized trading system, adapting ports in different parts of the world to the impacts of climate change is of considerable importance. Reflecting the views of a diverse group of stakeholders with expertise in climate science, engineering, economics, policy, and port management, this paper highlights the climate change challenge for ports and suggests a way forward through the adoption of some initial measures. These include both "soft" and "hard" adaptations that may be spearheaded by individual port entities, but will require collaboration and support from a broad range of public and private sector stakeholders and from society at large. In particular, the paper highlights a need to shift to more holistic planning, investment and operation.
\end{abstract}

Please cite as:

Becker, A., M. Acciaro, R. Asariotis, E. Carera, L. Cretegny, P. Crist, M. Esteban, A. Mather, S. Messner, S. Naruse, A.K.Y. Ng, S. Rahmstorf, M. Savonis, D. Song, V. Stenek, and A.F. Velegrakis. 2013. "A Note on Climate change adaptation for seaports: A challenge for global ports, a challenge for global society." Climatic Change 120 (4):683-695. doi: 10.1007/s10584-013-0843-z.

\section{Introduction}

Ports link international supply-chains and are critical to the global economy and trading system. At the same time, many of the world's ports, which handle over 80 percent of world trade, are highly vulnerable to a range of climate-related impacts, including temporary and permanent flooding arising from sea-level rise, high winds and storm surges (Hanson and Nicholls 2012; Asariotis and Benamara 2012). Service 
disruptions alone can cause total economic losses in the billions of euros/dollars (Haveman and Shatz 2006; Lloyds Loading List 2012) and may have important second-order consequences, not only for the regional economy and the quality of life of those who depend on the port's functionality, but also for the operation of global supply-chains. Established approaches to planning and decision making appear increasingly inappropriate due to the long time frames of climate impacts and short port-planning horizons, the lack of adequate data and of institutional arrangements to address regional and local climate effects, and the lack of engineering and design standards to guide decision makers in light of the changing climate. As noted in a U.S. National Academy of Sciences report, "The parameters of the new climate regime cannot be envisioned from past experience.... Decision makers will need new kinds of information and new ways of thinking and learning to function effectively in a changing climate...." (NRC 2009). Port managers need guidance and leadership on how climate change will affect their services and new institutional approaches are required to improve the long-term quality of their decisions for port resilience at the global level. Emerging from a 2011 United Nations Conference on Trade and Development (UNCTAD) meeting on the topic, this paper provides a consensus of expert opinions that includes port planners and operators, engineers, financers, economists, climate scientists and port policy makers (UNCTAD 2011). The multidisciplinary nature of the author team serves as an example of exactly the type of new stakeholder interaction and collaboration that is so critical for adaptation planning.

\section{Challenges for ports and for global society}

\subsection{A challenge for global ports}

Ports play a pivotal role in human civilization and commerce by serving as catalysts for economic growth and development (World Bank 2010). With more than $80 \%$ of global merchandise trade by volume and more than $70 \%$ by value being seaborne, ports constitute critical links in supply chains and production processes that rely on manufacturing, outsourcing and low-cost shipping (UNCTAD 1992). Indeed, ports are at the heart of international trade and globalization. At the sea-land interface where various transport modes converge, ports act as gateways to trade, providing access to global markets for both coastal and landlocked countries. Other economic activities, including industry, tourism and fisheries, also flourish around seaports. Shipping is a derived demand and grows in tandem with international trade. As trade and coastal populations increase, shipping volumes are set to rise considerably over coming decades (ASCE 2012) and the importance of ports to the global economy will only continue to grow (Levinson 2008).

Climate change poses substantial challenges to ports (Asariotis and Benamara 2012; Oh and Reuveny 2010) resulting from exposed locations in coastal zones, low-lying areas and deltas; long lifespans of key infrastructure assets; and interdependencies with trade, shipping and inland transport services that are also climatically vulnerable. The coastal or estuarine location of seaports suggests that mean sea level (MSL) rise, higher storm surges and river floods or droughts (Tebaldi et al. 2012; Von Storch et al. 2008; Jonkeren et al.), increased cyclone intensities/destructiveness (Elsner et al. 2008; Emanuel 2005) and potential changes in wave regimes (IPCC 2012) could cause operational delays in the billions of dollars per day (Haveman and Shatz 2006; EQECAT Inc. 2012; PANYNJ 2012). Recent global projections suggest sea levels could rise by as much as 1.9 meters by 2100 (Schaeffer et al. 2012; Vermeer and Rahmstorf 2009), which would exacerbate storm-surge impacts and wave damage in many regions (Lin et al. 2012; IPCC 2012) all the more if tropical storm intensities also increase (Bender et al. 2010; Knutson et al. 2010). These extreme events cause coastal inundation/erosion, wind hazards and inland floods that can disrupt entire transportation networks (USCCRP 2008). Some regions will find the local MSL rise exceeding the global mean, causing additional impacts from business losses to catastrophic disasters (et al. 2010; Hallegatte et al. 2011). Recent projections suggest a potentially crippling increase in asset exposure for the world's 136 port mega-cities in this century (Nicholls et al. 2008; Lenton et al. 2009). Already in the past decade unprecedented storm events have caused major damage along coastlines (Coumou and Rahmstorf 2012).

\section{Insert Figure 1 about here}

Between 1960 and 2010, at least one tropical storm passed within $50 \mathrm{~km}$ of $32 \%$ of the world's seaports (Figure 1). Many storms caused significant economic and environmental damage, such as hurricane "Katrina" that caused \$100m of damage to Mississippi's ports (PEER 2006) and hurricane "Sandy" that 
crippled the New York region, leading to a week long shut-down of one of the largest container ports in the U.S. and generating economic damages which could reach $\$ 50$ billion. Other climatic changes, e.g. increases in mean/extreme temperatures and precipitation changes may lead to equipment failures and severely disrupt port services; they may also affect tourism, agriculture and seafood production (USGCRP 2009), which could undermine the competitiveness of ports, particularly in developing regions with lowadaptive capacity (Tol et al. 2008; World Bank 2010; Esteban et al. 2012). The long lifetime of port assets, many of which were designed for a different climatic regime (USCCSP 2008), could result in infrastructure being 'under-designed' for the new climatic conditions of tomorrow. Against this background, adapting ports in different parts of the world to the impacts of climate change and building their resilience to these types of storm events is crucial. However, as a recent international survey revealed, few port authorities have begun to address this new challenge (Becker et al. 2012).

\subsection{A challenge for global society}

Port adaptation to climate change requires answers to some fundamental questions: What do we do? When do we do it? Who needs to act? Given the long service life of port infrastructure, effective adaptation requires re-thinking established approaches and practices early, as today's decisions may determine future vulnerability to climate change. As a society, we depend on ports and the public good they provide. However, no matter whether publicly owned or part of a public-private partnership, ports typically plan for short-term returns, not for conditions that could occur several decades in the future. Though ports certainly invest in their own infrastructure, public funding also plays a significant role. In the U.S. for example, engineers project a cumulative GDP loss of as much as $\$ 697$ billion by 2020 unless an additional $\$ 15.8$ billion shortfall is invested into the inland waterway and marine transportation system (USACE 2012) and this does not include climate adaptation. Adopting a global perspective, it is important to note the strong interdependence of ports in both developed and developing countries: in 2011, a total of 60 per cent of the volume of world seaborne trade was loaded and 57 per cent was unloaded in developing country ports (UNCTAD 2012). Climate-related risks, vulnerabilities and costs may be considerable, particularly for ports in developing regions, with low adaptive capacity. Given the strategic importance of ports for global trade flows, a failure by local decision-makers to take timely adaptation action may have much broader implications. In a globalized trading-system, where local decision-making may have global impacts, it is in everyone's interest to ensure the climate-resilience of critical transport infrastructure across regions.

\section{Strategies for Port Resilience}

\subsection{Engage full stakeholder network in resilience planning}

Ports, be they public or private, concern themselves first and foremost with their profit-driven bottom line. Decisions to invest in storm protections are weighed against other uses of funds and the probability of damage, though do not necessarily consider the catastrophic losses that can arise from a major episodic event. Major disaster risks are covered through insurance and/or a reliance on a government's ability to pick up the tab for repairs and cleanup. However, a wide variety of stakeholders face both economic and less tangible losses when a seaport is severely damaged or its operations are disrupted in a storm event. Ports may be aware that they should take appropriate precautions, but this does not at all mean that they have the incentive to do so. Port adaptation to climate change demands increased and new collaborations between stakeholders (Table 1) and consideration of interrelationships between ports and their surrounding regions. Since ports provide both private-sector profits and critical public services, stakeholders vary widely. For example, armoring a port and thus maintaining port revenues could result in tradeoffs with ecosystem services provided by existing natural areas, including tourism in adjacent communities. Likewise, efforts to climate-harden ports may be mooted by failures in hinterland port access routes or other essential network services such as power, communications and water. Identifying the stakeholders and creating dialogue among engineers, planners, investors, insurers, scientists, port and ship operators, regulators, and regional interest groups, as well as international organizations - to name but a few - is a critical first step. With much to gain from adaptation, port authorities are well positioned to catalyze new forms of collaboration. 


\subsection{Improve local climate projections and improve conditions for risk-assessment}

Reduction of port vulnerability requires an accurate identification of potential risks and impacts. Today, decision makers rely on information obtained from global models with low spatial-temporal resolution and sparse ground-truth. The uncertainty in global MSL projections is compounded by the expected regional variability in extreme events (IPCC 2012). Engineers and planners require better projections at the local/regional level to address the technical design of climate-resilient port infrastructure (Eriksson and Friis-Hansen 2011). Current guidance in the U.S. (USACE 2011) requires consideration of three sea level rise scenarios, where the highest assumes a global sea-level rise of 1.5 meters during the 21 st Century. Without a refinement of such projections (including storminess and wave climate projections (Mori et al. 2010), planning and implementation of appropriate resilience measures will be reactive at best. While better data is required, uncertainty in decision-making will also have to be factored into risk-assessment at the local levels. In view of the complexity of some of the issues at stake, targeted port case studies may significantly contribute to improved risk and vulnerability assessments (USCCSP 2008; UNCTAD 2011; UNCTAD 2008).

\subsection{Protect, elevate, or relocate?}

Sea level rise of up to 1.9 meters by 2100 indicates that many existing ports will face frequent inundation, even in moderate storm events. To become resilient, ports have three main options: update storm defenses, elevate to compensate for projected sea levels or relocate entirely. Each option is fraught with potential difficulties. Hard coastal defenses cause environmental problems - e.g., coastal erosion and habitat degradation (Airoldi et al. 2005) - and require massive investments. An elevated port can be rendered inoperable if its intermodal connections remain unprotected. Finally, port relocation requires the availability of an alternative location, with deep water and suitable transportation linkages - a rare commodity in most coastal areas. To add further complexity, any such response must take into account not just a higher sea level, but also the much-increased rate of sea level rise expected (Schaeffer et al. 2012). Major structural changes require enormous investment and must account for many uncertainties inherent in climate forecasts. For example, in new construction, the costs and benefits of an "adaptable terminal" design must be weighed against the construction of a stronger but less adaptable design (Headland et al. 2010). Financial consideration about when to undertake such adaptation strategies is still not clear. For instance, while some level of understanding exists concerning the stability of breakwaters against changes in sea levels and wave climate (Mase et al. 2013; Suh et al. 2013; Takagi et al. 2011), limited research has been carried out on the most appropriate time to reinforce these structures given climate projections (Headland et al. 2011).

Adaptation involves near-term and long-range planning that includes hard and soft interventions (Table 1). Generally hard interventions (i.e. engineering works) require high capital investments (human, material and financial), while soft interventions involve reducing uncertainty in decision-making, notably systematic and strategic management planning instruments such as land use management, financial incentives, evacuation schemes and, as noted by $\mathrm{Ng}$ et al. (2013), institutional changes. Ports can apply many low-cost intervention measures that can reduce climate risks and build a port's resilience before they resort to hard engineering works. As an example the deployment of emergency responders can enhance the success of evacuation plans. When considering any new plans/developments within a port system designers and port planners can factor climate change into their plans at an early stage, so as to provide for an uncertain future. For example, the construction of drainage systems take into account the potential increase in storm flows. Such "least regret" measures, apart from making good business sense, can help a port maintain its vital services in the face of climate stressors.

\subsection{Create enabling environment for investment in adaptation}

Ports provide benefits that extend beyond those of the operator or investor. Consequently, the interest in keeping this infrastructure operational goes beyond one group of stakeholders to include a wide set of public and private entities. Estimates of financing adaptation globally lie in the range of several hundred billion dollars per year (Nicholls et al. 2010), most of which is likely to come from private-sector sources, including as part of a "Green Climate Fund", set up to help finance mitigation and adaptation in developing countries (Green Climate Fund 2012). From the private-sector point of view, investments in adaptation are

likely to be treated similarly to other mainstream investments that require clarity of investment risks and generation of market returns. In addition, analysis of risks and returns on adaptation investments requires 
certainty about projected impacts, technological and other options that address the impacts, and resulting financial implications. Since private-sector entities lack the resources and capabilities to produce accurate climate projections, public entities need to provide an enabling environment through investment in information-technology transfer and also by provision of appropriate regulatory and legal frameworks and guidance. In addition, public and private sectors will need to combine resources and create new financing mechanisms to address adaptation challenges. This is especially true for infrastructure projects whose lifecycle spans several decades and whose ownership may change in a radically different climatic regime from the one in place during original construction.

\section{Ports at the forefront of addressing the adaptation challenge}

A number of seaports have already taken steps toward adaptation and offer valuable lessons on the development of best practices. For instance, the Port of Rotterdam (Netherlands) joined forces with other stakeholders to develop the Rotterdam Climate Proof Programme, which aims to make the city "fully" resilient to climate change impacts by 2025 and ensure that Rotterdam remains one of the safest port cities in the world. The adaptation strategy focuses on flood safety, accessibility for ships and passengers, adaptive building, the urban water system, and city climate. New port developments including port reconstruction are designed to be climate-proof and climate-change assessments are integrated into the port's spatial planning; to allow for dealing with uncertainties, knowledge development is considered an important pillar of the adaptation strategy (Vellinga and De Jong 2012).

The Port of San Diego (California) led a multi-stakeholder effort, The Climate Mitigation and Adaptation Plan, with the surrounding communities that share responsibility for emergency response, critical utilities protection, and stormwater drainage (Port of San Diego 2013; Messner and Moran 2013). The adaptation planning study included stakeholder input from the county, cities, port business leaders, port commissioners and staff, environmental NGO's, academic researchers, and the local utility. Planning for SLR and flooding focuses properties that serve a common function (- i.e. working areas of the port including hotels and restaurants, public recreation areas, natural areas and habitats, and areas of importance for public safety, e.g. utilities, roads). The assessment methodology included a risk evaluation framework that considered likelihood and consequence of impacts and prioritized according to risk classification (very high, high, medium, low, and N/A or no benefit).

The International Finance Corporation and the Port of Muelles el Bosque (Cartagena, Colombia) elaborated a climate risk study for the port and quantitatively assessed financial, and environmental and social impacts that are projected to result from the changing climate (Stenek 2011). The study analyzed projected changes in sea level rise, storm surge height, precipitation, temperature, and wind patterns, and direct and indirect effects of these on port assets, operations inside and outside of the port, surrounding environment and communities, and on the trade of the goods transported through the port. Where applicable, the effects of impacts were incorporated into the company's financial model, using the company's usual discount rate, allowing further assessment of cost effective adaptation options. Based on the conclusions of the study, the company announced plans for USD 30 million adaptation investments in two ports that it operates (Portafolio 2011), of which USD 12 million have already been invested (Stenek et al. 2011).

Finally, in Australia, the National Climate Change Adaptation Research Facility and RMIT University has developed a framework for studying the risk, vulnerability and resilience of the country's ports (McEvoy et al. 2013; McEvoy and Mullett 2013), which highlights that seaport adaptation to climate change, involves the development of practices in a range of areas. These include technology and engineering (e.g. cranes that operate safely under stronger winds, raising of connecting roadways/rail lines to respond to flooding); design and maintenance (e.g. accommodation of projected precipitation changes into future building designs); planning (e.g. planning of resilient logistic hubs in partnership with supply chain logistics infrastructure providers/local authorities); insurance (e.g. quantitative determination of unavoidable climate risks for appropriate insurance); and systems management (e.g. introduction of climate change considerations into environmental, logistics and risk/emergency management systems). Other studies have suggested specific practical steps, based on modeling of the wind regime inside a port, such as the reduction of wind loads through the building of permanent wind walls or transient wind protection by stacking containers to heights of up to $13-15 \mathrm{~m}$, which can decrease wind velocity for Ro-Ro vessels up to $25 \%$ and wind loads up to $30 \%$ (Paulauskas et al. 2009). 
These studies and initiatives demonstrate integrated and collaborative approaches to climate change response for ports and port regions. However, much more remains to be done and different approaches will have to be devised to cater for the variety of conditions facing ports at a global level.

\section{Conclusions}

Ports operate on the frontlines of climate change and at the heart of global development. As a strategic economic sector at risk, a paradigm shift in planning, investment and operation is not a choice but necessity. Our civilization relies on maritime transportation to carry its trade and drive growth. Some ports have begun to consider the future effects of climate change, such as Rotterdam, San Diego and Muelles el Bosque. However, these efforts are by no means generalized and many ports around the world are still largely unaware of the potential threats of climate change, or are slow to consider appropriate adaptation measures. Adaptation requires the development of organizational ability to respond effectively to climate change challenges, involving awareness raising, skill development, data collection and monitoring as well as focused research. Given the long timeframes and investment required to adapt ports to emerging environmental conditions, consideration for implementing large-scale projects should commence soon in both the public and private sectors. However, at present it remains unclear what adaptation strategies should be undertaken for different types of ports and on what timeline. Thus, future research is needed into the feasibility and prioritization of adaptation measures for specific ports, based on a better understanding of the range of specific threats that climate change and sea level rise pose. For the benefit of port businesses and society as a whole, decision makers must begin now on the long voyage of adapting to a new climate regime; this may also bring about additional co-benefits, such as improved logistics flows and more efficient management of the life cycle of infrastructure.

END 
Figure 1 -- Ports within 50km of tropical storm tracks 1960-2010. Port and storm data from (National Geospatial-Intelligence Agency 2011; Knapp et al. 2010).

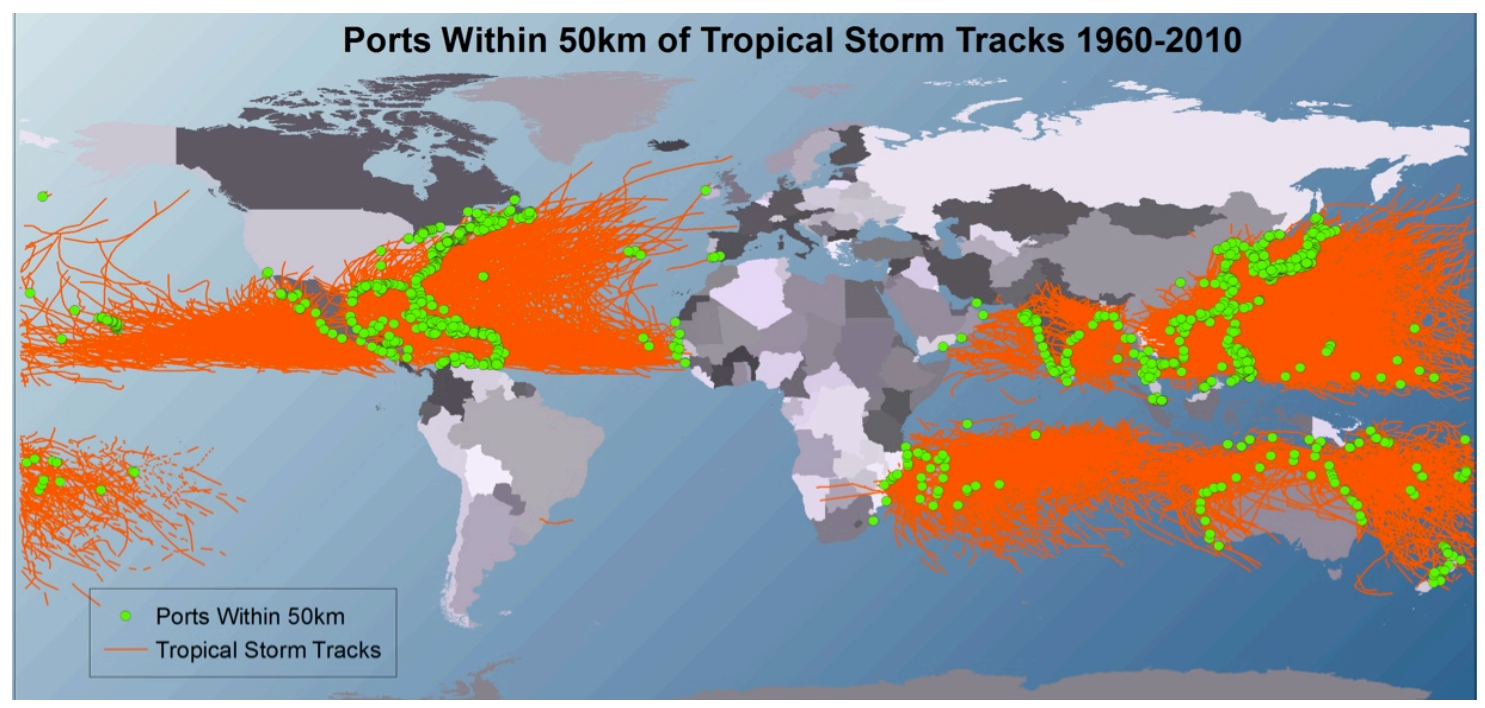


Table 1 - Select climate change impacts, responses and actors

Potential impacts from climate change:

Increase in height of waves that reach the port, flooding of port and transport installations, increase in coastal erosion, increased downtime due to flooding and higher winds, Increase sedimentation and erosion rates, Operational delays

Soft strategies and least regrets

Hard strategies
Possible responses

\section{Enhance emergency evacuation plans}

Consider adaptation in long-range plans

Learn from those at the forefront

Create financial instruments to support adaptation

Improve decision support tools and information

Increase standards of port construction to deal with higher winds

Increase funding for dredging and beach nourishment programs

Increase standards of port construction to deal with higher winds

Expand dredging and nourishment programs to handle increased quantity of sediment shifting

Increase Breakwater Dimensions

Move facilities and managed retreat

Raise port elevations

Raise transport levels or build coastal defenses

Build new coastal defenses

Increase port size to deal with bottlenecks
Actors to be engaged

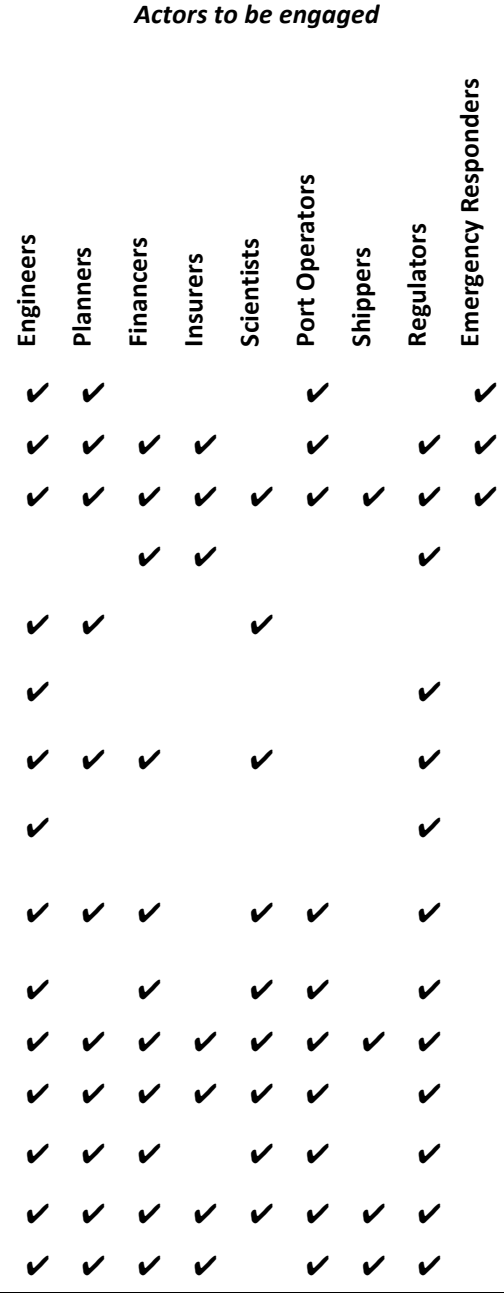


Table 2 -- Table of authors

\begin{tabular}{|c|c|c|c|c|}
\hline $\begin{array}{l}\text { First } \\
\text { Name }\end{array}$ & $\begin{array}{l}\text { Last } \\
\text { Name }\end{array}$ & Title & Affiliation & Email \\
\hline Austin $\mathrm{H}$. & Becker & $\begin{array}{l}\text { PhD Candidate, Emmett } \\
\text { Interdisciplinary Program } \\
\text { in Environment and } \\
\text { Resources }\end{array}$ & Stanford University; & austinb@stanford.edu \\
\hline Michele & Acciaro & $\begin{array}{l}\text { Senior Researcher, Green } \\
\text { Shipping \& Professor of } \\
\text { Maritime Logistics }\end{array}$ & $\begin{array}{l}\text { Det Norske Veritas \& The } \\
\text { Kühne Logistics University }\end{array}$ & Michele.Acciaro@the-klu.org \\
\hline Regina & Asariotis & $\begin{array}{l}\text { Chief, Policy and } \\
\text { Legislation Section, } \\
\text { Division on Technology } \\
\text { and Logistics }\end{array}$ & UNCTAD & Regina.Asariotis@unctad.org \\
\hline Edgard & Cabrera & $\begin{array}{l}\text { Chief, Marine Meteorology } \\
\text { and Ocean Affairs Division } \\
\text { Weather and Disaster Risk } \\
\text { Reduction Services } \\
\text { Department }\end{array}$ & $\begin{array}{l}\text { World Meteorological } \\
\text { Organization }\end{array}$ & ecabrera@wmo.int \\
\hline Laurent & Cretegny & Chief Economist & $\begin{array}{l}\text { Institute for Economic } \\
\text { Modeling }\end{array}$ & Laurent@cretegny.ch \\
\hline Philippe & Crist & Researcher & $\begin{array}{l}\text { International Transport } \\
\text { Forum/OECD }\end{array}$ & philippe.crist@oecd.org \\
\hline Miguel & Esteban & $\begin{array}{l}\text { Project Associate } \\
\text { Professor, Graduate } \\
\text { School of Frontier Sciences }\end{array}$ & University of Tokyo, Japan & esteban.fagan@gmail.com \\
\hline Andrew & Mather & $\begin{array}{l}\text { Project Executive: Coastal } \\
\text { Policy }\end{array}$ & Ethekwini Municipality & andrewmather@telkomsa.net \\
\hline Steven & Messner & Director & NextPlan & Steven.d.messner@live.com \\
\hline Susumu & Naruse & Secretary General & $\begin{array}{l}\text { International Association } \\
\text { or Ports and Harbors }\end{array}$ & s_naruse@iaphworldports.org \\
\hline $\begin{array}{l}\text { Adolf } \\
\text { K.Y. }\end{array}$ & $\mathrm{Ng}$ & $\begin{array}{l}\text { Associate Professor in } \\
\text { Transport and Logistics } \\
\text { Management }\end{array}$ & $\begin{array}{l}\text { I.H. Asper School of } \\
\text { Business, University of } \\
\text { Manitoba }\end{array}$ & adolf.ng@ad.umanitoba.ca \\
\hline Stefan & Rahmstorf & $\begin{array}{l}\text { Professor of Physics of the } \\
\text { Oceans }\end{array}$ & $\begin{array}{l}\text { Potsdam Institute for } \\
\text { Climate Impact Research }\end{array}$ & rahmstorf@ozean-klima.de \\
\hline Michael & Savonis & Senior Fellow & ICF International & msavonis@icfi.com \\
\hline $\begin{array}{l}\text { Dong- } \\
\text { Wook }\end{array}$ & Song & $\begin{array}{l}\text { Professor of Transport and } \\
\text { Logistics }\end{array}$ & $\begin{array}{l}\text { School of Engineering and } \\
\text { Built Environment } \\
\text { Edinburgh Napier } \\
\text { University }\end{array}$ & D.Song@napier.ac.uk \\
\hline Vladimir & Stenek & $\begin{array}{l}\text { Senior Climate Change } \\
\text { Specialist }\end{array}$ & $\begin{array}{l}\text { International Finance } \\
\text { Corporation }\end{array}$ & VStenek@ifc.org \\
\hline Adonis F. & Velegrakis & $\begin{array}{l}\text { Professor, Department of } \\
\text { Marine Sciences }\end{array}$ & University of the Aegean & adonis.velegrakis@hotmail.com \\
\hline
\end{tabular}

Acknowledgments: The authors thank the anonymous reviewers of this paper and the participants of the UNCTAD Ad Hoc Expert Meeting on Climate change impacts and adaptation: A challenge for global ports (29-30 September, 2011) for ideas, input, and review. 


\section{References and notes}

Airoldi L, Abbiati M, Beck M, Hawkins S, Jonsson PR, Martin D, Moschella P, Sundelöf A, Thompson R, Åberg P (2005) An ecological perspective on the deployment and design of low-crested and other hard coastal defence structures. Coastal Engineering 52 (10):1073-1087

Asariotis R, Benamara H (eds) (2012) Maritime Transport and the Climate Change Challenge. Earthscan/Routledge, New York, NY

ASCE (American Society of Civil Engineers) (2012) Failure to act: The economic impact of current investment trends In airports, inland waterways, and marine ports infrastructure.

http://www.uwace.org/reportcard. Accessed 05 May, 2013

Becker A, Inoue S, Fischer M, Schwegler B (2012) Climate change impacts on international seaports: knowledge, perceptions, and planning efforts among port administrators. Climatic Change 110 (1):5-29

Bender MA, Knutson TR, Tuleya RE, Sirutis JJ, Vecchi GA, Garner ST, Held IM (2010) Modeled impact of anthropogenic warming on the frequency of intense Atlantic hurricanes. Science 327 (5964):454-458. doi:10.1126/science. 1180568

Coumou D, Rahmstorf S (2012) A decade of weather extremes. Nature Climate Change 2 (7):491-496

Elsner JB, Kossin JP, Jagger TH (2008) The increasing intensity of the strongest tropical cyclones. Nature 455 (7209):92-95

Emanuel K (2005) Increasing destructiveness of tropical cyclones over the past 30 years. Nature 436 (7051):686-688

EQECAT Inc. (2012) Post-landfall loss estimates - Hurricane Sandy - Nov. 1, 2012 (Insured Losses: \$10 20 Billion; Total Economic Damage: $\$ 30$ - 50 Billion).

Eriksson K, Friis-Hansen P (2011) Risk based adaptation to climate change. Proceedings of the World Renewable Energy Congress 2011 (WREC 2011), 9-13 May, Linköping: Volume 2 Climate Change Issues. Linköping University Electronic Press,

Esteban M, Thao ND, Takagi H, Shibayama T (2012) Increase in Port Downtime and Damage in Vietnam Due To a Potential Increase in Tropical Cyclone Intensity. In: Climate Change and the Sustainable Use of Water Resources. Springer, pp 101-125

Esteban M, Webersik C, Shibayama T (2010) Methodology for the estimation of the increase in time loss due to future increase in tropical cyclone intensity in Japan. Climatic Change 102 (3):555-578

GCRP (United States Global Change Research Program) (2009) Global Climate Change Impacts in the United States. Cambridge University Press, http://www.globalchange.gov/publications/reports/scientific-assessments/us-impacts

Green Climate Fund (2012) Green Climate Fund. http://gcfund.net/home.html. Accessed 4 December 2012

Hallegatte S, Ranger N, Mestre O, Dumas P, Corfee-Morlot J, Herweijer C, Wood RM (2011) Assessing climate change impacts, sea level rise and storm surge risk in port cities: a case study on Copenhagen. Climatic change 104 (1):113-137

Hanson S, Nicholls RJ (2012) Extreme flood events and port cities through the twenty-first century. In: Asariotis R, Benemara, H. (ed) Maritime Transport and the Climate Change Challenge. Earthscan/Routledge, New York, NY, p 243

Haveman JD, Shatz HJ (2006) Protecting the nation's seaports: Balancing security and cost. http://www.ppic.org/content/pubs/report/r_606jhr.pdf.

Headland JR, Trivedi D, Boudreau RH Coastal Structures and Sea Level Rise: Adaptive Management Approach. In: Coastal Engineering Practice (2011), 2010. ASCE, pp 449-459

Intergovernmental Panel on Climate Change (2012) IPCC Special Report on Managing the Risks of Extreme Events and Disasters to Advance Climate Change Adaptation. A Special Report of Working Groups I and II of the Intergovernmental Panel on Climate Change. Cambridge University Press.

Jonkeren O, Rietveld P, van Ommeren J, te Linde A Climate change and economic consequences for inland waterway transport in Europe. Regional Environmental Change:1-13

Knapp KR, Kruk MC, Levinson DH, Diamond HJ, Neumann CJ (2010) The International Best Track Archive for Climate Stewardship (IBTrACS): Unifying tropical cyclone best track data. Bulletin of the American Meteorological Society 91:363-376 
Knutson TR, McBride JL, Chan J, Emanuel K, Holland G, Landsea C, Held I, Kossin JP, Srivastava AK, Sugi M (2010) Tropical cyclones and climate change. Nature Geoscience 3:157-163. doi:10.1038/ngeo779

Lenton T, Footitt A, Dlugolecki A (2009) Major Tipping Points in the Earth's Climate System and Consequences for the Insurance Sector. http://awsassets.panda.org/downloads/plugin_tp_final_report.pdf.

Levinson M (2008) The box: how the shipping container made the world smaller and the world economy bigger. Princeton University Press, Princeton, NJ

Lin N, Emanuel K, Oppenheimer M, Vanmarcke E (2012) Physically based assessment of hurricane surge threat under climate change. Nature Climate Change 2:462-467. doi:doi:10.1038/nclimate1389

Lloyds Loading List (2012) US Port Strike Ends. http://www.lloydsloadinglist.com.

Mase H, Tsujio D, Yasuda T, Mori N (2013) Stability analysis of composite breakwater with wavedissipating blocks considering increase in sea levels, surges and waves due to climate change. Ocean Engineering In Press. doi:http://dx.doi.org/10.1016/j.oceaneng.2012.12.037

McEvoy D, Mullett J (2013) Enhancing the resilience of seaports to a changing climate: research synthesis and implications for policy and practice. Enhancing the resilience of seaports to a changing climate report series. National Climate Change Adaptation Research Facility, Gold Coast, Australia

McEvoy D, Mullett J, Millin S, Scott H, Trundle A (2013) Understanding future risks to ports in Australia. Enhancing the resilience of seaports to a changin climate report series. National Climate Adaptation Research Facility, Gold Coast, Australia, Gold Coast, Australia http://www.nccarf.edu.au/sites/default/files/attached_files_publications/Final-report-Climateresilient-ports-series--Risk-WP1-Web 21 Mar.pdf

Messner S, Moran L (2013) Climate change and sea level rise impacts at ports and a consistent methodology to evaluate vulnerability and risk. WIT Transactions on Ecology and the Environment 169. doi:10.2495/13CP0131

Mori N, Yasuda T, Mase H, Tom T, Oku Y (2010) Projection of extreme wave climate change under global warming. Hydrological Research Letters 4:15-19

National Geospatial-Intelligence Agency (2011) World Port Index, 21st Edition. http://msi.nga.mil/MSISiteContent/StaticFiles/NAV_PUBS/WPI/wpi.zip. Accessed 15 September 2012

National Research Council (2009) Informing Decisions in a Changing Climate. The National Academies Press. http://www.nap.edu/catalog.php?record_id=12626.

$\mathrm{Ng}$ AKY, Becker A, Fischer M (2013) A theoretical discussion on climate change, port adaptation strategies and institutions. Paper presented at the Proceedings of the Canadian Transportation Research Forum, Halifax, NS, Canada, 10-12 June

Nicholls RJ, Brown SB, Hanson S, Hinkel J (2010) Economics of coastal zone adaptation to climate change. International Bank for Reconstruction and Development / World Bank. http://eprints.soton.ac.uk/id/eprint/202135.

Nicholls RJ, Hallegatte S, Corfee-Morlot J, Chateau J, Muir-Wood R, Hanson S, Herweijer C, Patmore N (2008) Ranking Port Cities with High Exposure and Vulnerability to Climate Extremes. OECD. doi: $10.1787 / 011766488208$

Oh CH, Reuveny R (2010) Climatic natural disasters, political risk, and international trade. Global Environmental Change 20 (2):243-254

PANYNJ (Port Authority of New York and New Jersey) (2012) Press Release (183-2012). 4 November 2012,

Paulauskas V, Paulauskas D, Wijffels J (2009) Ships Safety In Open Ports. Computer Modelling and New Technologies 13 (2):48-55

PEER (Joint Legislative Committee on Performance Evaluation and Expenditure Review) (2006) The Impact of Hurricane Katrina on Mississippi's Commercial Public Ports and Opportunities for Expansion of the Ports. http://www.peer.state.ms.us.

Port of San Diego (2013) The Climate Mitigation and Adaptation Plan of the Port of San Diego. http://www.portofsandiego.org/climate-mitigation-and-adaptation-plan.html. Accessed 15 June 2013

Rotterdam Climate Initiative (2013) Rotterdam Climate Initiative. http://www.rotterdamclimateinitiative.nl. Accessed 21 June 2013 
Schaeffer M, Hare W, Rahmstorf S, Vermeer M (2012) Long-term sea-level rise implied by 1.5 degrees C and 2 degrees $C$ warming levels. Nature Climate Change 2:867-870

Stenek V, J.C. Amado R, Connell O, Palin S, Wright B, Pope J, Hunter J, McGregor W, Morgan B, Stanley R, Washington D, Liverman H, Sherwin P, Kapelus C, Andrade J, Pabon D (2011) Climate Risk and Business: Ports.

Suh KD, Kim SW, Kim S, Cheon S (2013) Effects of climate change on stability of caisson breakwaters in different water depths. Ocean Engineering In Press. doi:http://dx.doi.org/10.1016/j.oceaneng.2013.02.017

Takagi H, Kashihara H, Esteban M, Shibayama T (2011) Assessment of future stability of breakwaters under climate change. Coastal Engineering Journal 53 (01):21-39

Tebaldi C, Strauss BH, Zervas CE (2012) Modelling sea level rise impacts on storm surges along US coasts. Environmental Research Letters 7 (1):014032

Tol RSJ, Klein RJT, Nicholls RJ (2008) Towards Successful Adaptation to Sea-Level Rise along Europe's Coasts. Journal of Coastal Research 24 (2):432-442. doi:10.2112/07a-0016.1

UNCTAD (United Nations Conference on Trade and Development) (1992) Development and Improvement of Ports-The Principles of Modern Port Management and Organization. Trade and Development Board, Committee on Shipping, Ad hoc Intergovernmental Group of Port Experts. $\mathrm{TD} / \mathrm{B} / \mathrm{C} .4 / \mathrm{AC} .7 / 13$

UNCTAD (United Nations Conference on Trade and Development) (2008) Maritime transport and the climate change challenge. Note by the UNCTAD secretariat. United Nations, Geneva, TD/B.C.I/MEM.1.2

UNCTAD (United Nations Conference on Trade and Development) (2011) Main Outcomes and Summary of Discussions Climate Change Impacts and Adaptation: A Challenge for Global Ports, Ad Hoc Expert Meeting. Geneva, Switzwerland. doi:UNCTAD/DTL/TLB/2011/3, http://www.unctad.org/ttl/legal

UNCTAD (United Nations Conference on Trade and Development) (2012) Review of Maritime Transport, 2012. UNCTAD/RMT/2012. Geneva, Switzerlandhttp://unctad.org/en/PublicationsLibrary/rmt2012_en.pdf

USACE (United States Army Corps of Engineering) (2011) Sea-Level Change Considerations for Civil Work Programs. Circular No. 1165-2-212.

USCCSP (United States Climate Change Science Program) (2008) Impacts of Climate Change and Variability on Transportation Systems and Infrastructure: Gulf Coast Study, Phase I. Transportation Do. http://www.climatescience.gov/Library/sap/sap4-7/final-report/.

Vellinga T, De Jong M (2012) Approaches to climate change adaptation in the Port of Rotterdam. In: Asariotis R, Benamara, H. (ed) Maritime Transport and the Climate Change Challenge. p 305

Vermeer M, Rahmstorf S (2009) Global sea level linked to global temperature. Proceedings of the National Academy of Sciences 106 (51):21527

Von Storch H, Gönnert G, Meine M (2008) Storm surges-An option for Hamburg, Germany, to mitigate expected future aggravation of risk. Environmental Science \& Policy 11 (8):735-742

World Bank (2010) The Costs to Developing Countries of Adapting to Climate Change: New Methods and Estimates. In: Global Report of the Economics of Adaptation to Climate Change Study. The World Bank Group,, Washington, DC, USA, 